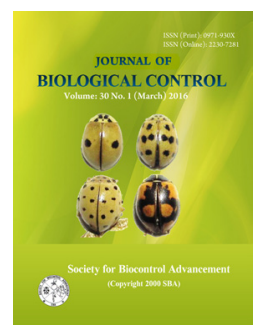

\title{
Efficacy of substrate based bioformulation of microbial antagonists in the management of bacterial disease of some solanaceous vegetables in Assam
}

\author{
POPY BORA*, L. C. BORA ${ }^{1}$ and P. C. DEKA \\ Krishi Vigyan Kendra, Assam Agricultural University, Sonitpur, Assam, India \\ ${ }^{1}$ Department of Plant Pathology, Assam Agricultural University (AAU), Jorhat - 13, India \\ Corresponding author_E-mail: popy_aau@yahoo.com
}

\begin{abstract}
A study was undertaken to explore effective organic substrate-based bioformulation using virulent cells of antagonists Pseudomonas fluorescens, Bacillus subtilis and Trichoderma viride during 2010-13. Three organic substrates, viz. vermicompost, farm yard manure and mustard oil cake (MOC) were compared for mass multiplication of the antagonists. All the substrate based antagonists showed effective results in suppression of bacterial wilt (Ralstonia solanacearum Yabuchi et al.) incidence in vegetable crops tomato, brinjal and chill. Quantitative aspect of population dynamics of the antagonists at different days of storage was made to evaluate the shelflife of the biopesticide and found that the antagonists maintained a steady population count upto 180 days of storage at room temperature. The combination of vermicompost $P$. fluorescens, carboxy methyl cellulose (CMC) and mannitol showed best shelf-life as it maintained highest population recovery of $P$. fluorescens and B. subtillis at different days of storage. The combination of MOC, T. viride, CMC and mannitol showed best shelf-life in case of $T$. viride and maintained highest population recovery of the antagonist at different days of storage. Application of the substrate based bioformulations as combination of seed treatment, root application, soil application at transplanting and soil application at 30 days after transplanting showed minimum wilt incidence and maximum yield in tomato, brinjal and chilli. Maximum disease reduction (81.85\%) was shown by bioformulation comprising $P$. fluorescens with vermicompost as substrate followed by T. viride with MOC as substrate (79.07\%). Following the trend of reduction in disease incidence, yield was maximum in tomato (36.0 $\mathrm{t} /$ ha), when the crop was treated with vermicompost based $P$. fluorescens followed by treatment with MOC based $T$. viride (33.35 t/ha). Yield of brinjal (27.60 t/ha) and chilli (26.30 t/ha) was similarly maximum when bioformulation of vermicompost based $P$. fluorescens was applied.
\end{abstract}

KEY WORDS: Antagonists, bioformulation, chilli, tomato, wilt

(Article chronicle: Received: 04-11-2015 ; Revised: 04-02-2016; Accepted: 15-03-2016)

\section{INTRODUCTION}

Solanaceous vegetables constitute a major group of economically important vegetables in Assam of which tomato, brinjal and chilli are most extensively cultivated in the state. Tomato cultivation covers an area of 12,550 hectares with productivity of 16.5 tonnes/hectare. Similarly, brinjal and chillies are grown in about 26,000 and 13,400 hectares with productivity of 15.2 tonnes/ha and 13.5 tonnes/ha, respectively. However, Ralstonia solanacearum incited wilt disease is one of the major yield limiting factors of solanaceous vegetables in Assam and causes severe losses ranging from 92 to 100 per cent, when environmental conditions become favourable for pathogen manifestations (Bora and Bora, 2008; Bora and Bora, 2009). Means to control R. solanacearum incited bacterial wilt disease are limited. Various tactics like crop rotation is not a viable as the bacterium is soil inhabitant and persist indefinitely in infested fields (Chellemi et al., 1994), use of antibiotics frequently leads to development of resistance races of the pathogen (Sigee, 1993), use of resistant cultivar was most logical solution but break down of resistance is quite common due to intensive cultivation. To combat the limitation of these management practices, presently plant disease management has been directed towards the environmentally safe and economically feasible bio-intensive strategy as the alternative means for plant disease management. In this context, exploitation of saprophytic antagonists as biological control agent has been considered as suitable tactic, as it is environmentally safe and economically feasible. Strains of fluorescent pseudomonads, Trichoderma spp. and Bacillus spp. are known 
antagonists against soil borne plant pathogens and attempts have been made throughout the world to explore the possibilities of using these saprophytic antagonists for crop disease management (Burr et al., 1978; Papavizas, 1985; Bull, 1987; Anuratha and Gnanamanickam, 1990; Nautyal, 2000; Bora et al., 2000; Bora and Deka, 2007; Bora, 2008; Bora and Bora, 2008).

In the light of these factors, present study was undertaken to explore the potential of an environment friendly strategy with bioformulation of Pseudomonas fluorescens, Bacillus subtilis and Trichoderma viride to combat disease of solanaceous vegetable crops (tomato, brinjal and chilli).

\section{MATERIALS AND METHODS}

Different experiments were conducted in the laboratory of the Department of Plant Pathology, Assam Agricultural University, Jorhat and farmers field of Sonitpur district. Diseased tomato, brinjal and chilli plants showing symptoms of bacterial wilt were used for the isolation of $R$. solanacearum using triphenyl tetrazolium chloride (TTC) medium. The inoculum concentration of the pathogen was always adjusted to a bacterial population of $1 \mathrm{x}$ $10^{8}$ colony forming units per milliliter $(\mathrm{cfu} / \mathrm{ml})$. The pure cultures of the antagonists were collected from the culture stock of the Department of Plant Pathology, AAU, Jorhat. King'B agar media and potato dextrose agar (PDA) media were used for the multiplication and preservation of Pseudomonas fluorescens, B. subtilis and T. viride respectively.

The organic substrates used for the mass multiplication of antagonists were vermicompost (VC), farm yard manure (FYM) and mustard oil cake (MOC). The substrates were air dried and passed through 350 mesh sieves to obtain fine powders. These were filled into polypropylene bags separately, sealed with non-absorbent cotton plugs and sterilized at $121^{\circ} \mathrm{C}$ for 30 minutes. Mass culture of fluorescent pseudomonad strain P. fluorescens was prepared by transferring aseptically its $24 \mathrm{~h}$ old growth in $\mathrm{KB}$ agar into $1000 \mathrm{ml} \mathrm{KB}$ broth and incubated at $28^{\circ} \mathrm{C}$ for $24 \mathrm{~h}$. Similarly, mass cultures of B. subtilis and T. viride was prepared by transferring aseptically their $72 \mathrm{~h}$ old growth in PDA to $1000 \mathrm{ml} \mathrm{PD}$ broth and incubated at $28^{\circ} \mathrm{C}$ for $120 \mathrm{~h}$. From these, $10 \mathrm{ml}$ of the P. fluorescens and B. subtilis cells $\left(10^{7} \mathrm{cfu} / \mathrm{ml}\right)$ and $10 \mathrm{ml}$ of $T$. viride cells $\left(10^{7} \mathrm{cfu} / \mathrm{ml}\right)$ respectively were added to the sterilized substrates contained in the polypropylene bags. A standard sticker, carboxy-methyl cellulose (CMC @ 1\%) was added in order to impart greater adherence property and a standard osmoticant (Mannitol@ @3\%) was added to impart higher moisture retaining property to the substrates. The inoculated substrates were then mixed properly and the mixtures of substrates $+P$. fluorescens; substrates $+B$. subtilis; substrates $+T$. viride along with CMC and Mannitol were incubated at $28^{\circ} \mathrm{C}$ for $72 \mathrm{~h}$. The bags were stored at room temperature after incubation.

For determination of the population of $P$. fluorescens, $B$. subtilis and $T$. viride in different substrate formulation after different days of storage as prepared above, experiment was designed following completely randomized design with 3 replications. The 10 different treatment combinations were : $\mathrm{VC}+$ P. fluorescens; $\mathrm{VC}+B$. subtilis; $\mathrm{VC}+$ T. viride; FYM + P. fluorescens; FYM + B. subtilis; FYM + T. viride; $\mathrm{MOC}+$ P. fluorescens; $\mathrm{MOC}+$ B. subtilis; $\mathrm{MOC}$ $+T$. viride; and control. The viable population of P. fluorescens; $B$. subtilis and $T$. viride in different substrates was determined after $60,120,180,240$ and 300 days of inoculation following dilution plate technique to ascertain the best antagonist + substrate combination for highest shelf life of the formulation in storage at room temperature.

The field experiment was carried out with pot grown tomato, brinjal and chilli plants to evaluate the best method of application of the substrate based antagonists in management of bacterial wilt disease of these vegetable crops. All together 10 treatments were imposed, arranged in RBD and each replicated 4 times. The best substrate based bioformulation of $P$. fluorescens, B. subtilis and $T$. viride was applied in tomato, brinjal, and chilli as seed treatment, root treatment, soil treatment and their combinations at the time of transplanting and at 30 days after transplanting.

For seed treatment, seeds of tomato, brinjal and chillies respectively, were first cleaned individually and treated with the bioformulation @1 gm/gm of seed along with a sticker/adhesive like rice glue for easy adherence. The coated seeds were then spread over a clean paper and dried overnight. For root treatment of seedlings, the bioformulation was mixed with rice gruel to form fine slurry and the roots of the seedlings were dipped in it for about 30 minutes. For 1000 seedlings of each crop $1 \mathrm{~kg}$ of bioformulation was required. The treated roots were dried for 1 hour under shade before transplanting. For soil treatment at the time of transplanting, $10 \mathrm{~g}$ of bioformulation was mixed with $100 \mathrm{~g}$ of vermicompost (@10 kg bioformulation mixed with $1 \mathrm{qt}$ vermicompost/ha) and was applied to the soil near the root zone of the crops. Similarly, the same treatment soil application of bioformulation was repeated at 30 days after transplanting. Observations were made on the wilt incidence (\%) in each crop and yield (t/ha) for all the treatments in each crop. 


\section{RESULTS AND DISCUSSION}

Population of antagonists in various substrate based formulations after different days of storage:

The mean population of all the three antagonists in formulations of three substrates significantly increased upto 180 days of storage after which it showed declining trend (Table 1). The highest population of $P$. fluorescens $\left(112.43 \times 10^{7} \mathrm{cfu} / \mathrm{g}\right)$ was recovered from formulation where vermicompost was used as substrate. While the least population of $P$. fluorescens was recovered from the formulation where MOC was used as substrate. Similarly, the highest population $\left(71.17 \times 10^{7} \mathrm{cfu} / \mathrm{g}\right)$ of $B$. subtilis was recovered when vermicompost was used as substrate, while least population was recovered when MOC was used as substrate. On the other hand, the highest population of $T$. viride $\left(108.83 \times 10^{7} \mathrm{cfu} / \mathrm{g}\right)$ was recovered from formulation comprising of MOC as substrate after 180 days of storage. The lowest population of $T$. viride was recovered from the formulation comprising FYM as substrate. On an average, vermicompost among the substrates appeared to be the best nutrient source to support the antagonists for maximum multiplication and subsequently better disease reduction. Earlier, Suslow and Schroth (1982) reported that fluorescent pseudomonad $P$. fluorescens could survive 7 months to 1 year with a higher population level when it was incorporated into carrier materials viz., talc or peat along with CMC. The higher population of antagonists might be due to high nutrient content of vermicompost, which is a good source of humus, Vitamin-B, auxin and antibiotics. Moreover, it contains 2.5-3.5 per cent nitrogen, 1.5-2.0 per cent phosphorous and 2.0-3.5 per cent potassium (Kohli et al., 1988). Vermicompost causes a shift of $\mathrm{pH}$ towards neutral, a reduction in electrical conductivity, and therefore fluorescent pseudomonad, P. fluorescens, which prefers neutral to alkaline $\mathrm{pH}$ tends to exhibit higher population shift in vermicompost (Alexander, 1997). CMC was used in the formulation as an adhesive, which might have also played a role of preservative for the long-term viability of the antagonist. Moreover, mannitol used as osmoticant, has the ability to protect the antagonist from desiccation and thereby increases their survivality (Vidhyasekaran and Muthamilan, 1995). Population dynamics of $B$. subtilis might have similarly supported by vermicompost, when it was used as substrate. However, T. viride showed higher population count when MOC was used as its substrate. MOC as substrate might have helped T. viride in better sporulation and production of colony forming units as it could release enzymes like $\beta-1-3$ glucanase and chitinase and these might have helped the fungi during utilization of cellulose and chitin present in different substrates (Hadar et al., 1979). Trichoderma spp., multiply faster at higher concentration of $\mathrm{CO}_{2}$, a condition favoured by MOC as substrate. Similarly, it might also have been favoured by humic acid present in the MOC (Ushasree et al., 1989).

Efficacy of the substrate based formulations of Pseudomonas fluorescens, Bacillus subtilis and Trichoderma viride on reduction of bacterial wilt incidence in tomato, brinjal and chilli

All the treatment combinations, irrespective of antagonist and substrate used, were significantly effective in lowering wilt of tomato brinjal and chilli crops (Table 2). However, $P$. fluorescens along with vermicompost and T. viride along with $\mathrm{MOC}$ as substrate were significantly most effective in reducing disease incidence. Data also depicted that B. subtilis along with MOC as substrate was least effective in reducing disease incidence.

Maximum disease reduction ( $81.85 \%$ ) was shown by bioformulation comprising $P$. fluorescens with vermicompost as substrate followed by $T$. viride with MOC as substrate $(79.07 \%)$, while least disease reduction $(54.33 \%)$ was shown by $B$. subtilis with MOC as substrate followed by T. viride with vermicompost as substrate $(54.92 \%)$.

Better disease reduction in tomato caused by $R$. solanacearum was earlier recorded by using $P$. fluorescens as seed and seedling inoculation. Fluorescent pigments produced by the pseudomonads sequester $\mathrm{Fe}^{3+}$ and are considered siderophores, which inhibits large number of phytopathogenic bacteria and fungi in soil (Aspiras and Della Cruz, 1985). Similarly, Kloepper and Schroth (1981) reported that fluorescent pseudomonad could rapidly colonize and inhibit certain components of the root zone microflora and along with rich substrate the antagonist beneficially alter the composition of the rhizosphere leading to reduced plant disease incidence. However, T. viride with MOC as substrate was more effective in reduction of disease incidence in ginger. MOC might have helped T. viride in better sporulation, production of colony forming units and subsequent higher reduction of disease incidence in ginger. Danielson and Davey (1973) reported that Trichoderma spp., multiply faster at higher concentration of $\mathrm{CO}_{2}$ and when substrates like MOC containing carbon are degraded, $\mathrm{CO}_{2}$ is evolved. From above discussion, it is evident that substrates like vermicompost, FYM and MOC enhances the activity of antagonists, which complete with the soil borne plant pathogen for nutrient and space. 
The addition of antagonists along with different substrates might have influenced of soil organic carbon. Earlier, Hoitink and Fahy (1986) tried to establish positive correlation between $\mathrm{C}: \mathrm{N}$ ratio of residues of organic carbon and disease severity. Similarly, an increase in the available phosphorus content of soil has been reported to be effective in suppressing the disease incidence. The substrates particularly vermicompost increases available phosphorus content in the soil in contrast to the other treatment, which could provide maximum protection to the plants from the disease. The increased availability of phosphorus and potash in soil might have contributed towards the resistance of the plants to the diseases as have been recorded in many other pathogens (Sharif et al., 2003).

Efficacy of substrate based bioformulation of Pseudomonas fluorescens, Bacillus subtilis and Trichoderma viride on yield of tomato, brinjal and chilli

The yield of all the crops increased significantly when plants were treated with P. fluorescens, B. subtilis and T. viride based bioformulation, following different methods (Table 3). Following the trend of reduction in disease incidence, yields was maximum in tomato $(36.0 \mathrm{t} / \mathrm{ha})$, when the crop was treated with vermicompost based $P$. fluorescens applied as seed treatment + root treatment + soil application at transplanting + soil application at 30 days after transplanting (DAT). This was followed by treatment with
MOC based T. viride (33.35 t/ha). Yield of brinjal (27.60 t/ ha) and chilli (26.30 t/ha) was similarly maximum when bioformulation of vermicompost based $P$. fluorescens was applied. Least yield of brinjal (17.33 t/ha) and chilli (15.42 $\mathrm{t} / \mathrm{ha}$ ) was recorded in the treatment comprising bioformulation of MOC based B. subtilis.

Successful biological control agents like fluorescent pseudomonads, B. subtilis and T. viride have the ability to compete with other members of the soil microflora and also to produce antibiotics or induce a response in the host that favours growth of the plant beneficial microbes while inhibiting the growth of the pathogen like $R$. solanacearum. Simultaneous application of two or more compatible antagonists led to their higher population densities in the rhizosphere and the density dependent mechanism might have prevailed by rapid rhizosphere colonization, and thereby led to rhizosphere niche exclusion in terms of space and nutrients for the pathogen and ultimately reduction of wilt incidence and corresponding enhancement of crop yields. Such mechanisms have been demonstrated by Bull (1987), and explained that the wheat take-all disease control and enhancement of crop yield by biological means was directly related to the rapid root colonization by antagonist like $P$. fluorescens. Moreover, the efficiency of biocontrol agents with organic substrates is depended on method of introduction, rate of inoculum density of the

Table 1. Population of Pseudomonas fluorescens, Bacillus subtilis and Trichoderma viride assayed from substrate based bioformulations after different days of storage

\begin{tabular}{|c|c|c|c|c|c|c|}
\hline \multirow[t]{2}{*}{ TREATMENTS } & \multicolumn{6}{|c|}{ Population of antagonists $\left(\mathrm{x} 10^{7} \mathrm{cfu} / \mathrm{g}\right)$ after different days of storage } \\
\hline & 60 & 120 & 180 & 240 & 300 & Mean \\
\hline Vermicompost $(\mathrm{VC})+P$. fluorescens & $\begin{array}{l}64.33 \\
(1.80)\end{array}$ & $\begin{array}{l}90.50 \\
(1.96)\end{array}$ & $\begin{array}{c}112.43 \\
(2.05)\end{array}$ & $\begin{array}{l}86.10 \\
(1.93)\end{array}$ & $\begin{array}{l}16.48 \\
(1.21)\end{array}$ & $\begin{array}{l}73.97 \\
(1.86)\end{array}$ \\
\hline Farm yard manure $(\mathrm{FYM})+P$. fluorescens & $\begin{array}{l}34.50 \\
(1.54)\end{array}$ & $\begin{array}{l}60.00 \\
(1.77)\end{array}$ & $\begin{array}{l}72.88 \\
(1.86)\end{array}$ & $\begin{array}{l}57.87 \\
(1.76)\end{array}$ & $\begin{array}{c}07.45 \\
(0.87)\end{array}$ & $\begin{array}{l}46.54 \\
(1.66)\end{array}$ \\
\hline Mustard oil cake $(\mathrm{MOC})+P$. fluorescens & $\begin{array}{l}16.50 \\
(1.22)\end{array}$ & $\begin{array}{l}26.50 \\
(1.42)\end{array}$ & $\begin{array}{l}27.89 \\
(1.44)\end{array}$ & $\begin{array}{l}22.17 \\
(1.35)\end{array}$ & $\begin{array}{c}05.30 \\
(0.72)\end{array}$ & $\begin{array}{l}19.67 \\
(1.29)\end{array}$ \\
\hline $\mathrm{VC}+T$. viride & $\begin{array}{l}42.55 \\
(1.63)\end{array}$ & $\begin{array}{l}64.50 \\
(1.81)\end{array}$ & $\begin{array}{l}75.66 \\
(1.66)\end{array}$ & $\begin{array}{l}74.27 \\
(1.87)\end{array}$ & $\begin{array}{l}02.15 \\
(0.33)\end{array}$ & $\begin{array}{l}51.83 \\
(1.71)\end{array}$ \\
\hline $\mathrm{FYM}+T$. viride & $\begin{array}{l}25.99 \\
(1.41)\end{array}$ & $\begin{array}{l}49.50 \\
(1.69)\end{array}$ & $\begin{array}{l}51.50 \\
(1.71)\end{array}$ & $\begin{array}{l}33.10 \\
(1.52)\end{array}$ & $\begin{array}{c}01.50 \\
(0.17)\end{array}$ & $\begin{array}{l}32.32 \\
(1.51)\end{array}$ \\
\hline $\mathrm{MOC}+T$. viride & $\begin{array}{l}62.83 \\
(1.80)\end{array}$ & $\begin{array}{l}91.17 \\
(1.96)\end{array}$ & $\begin{array}{l}108.83 \\
(2.04)\end{array}$ & $\begin{array}{l}71.50 \\
(1.85)\end{array}$ & $\begin{array}{c}07.50 \\
(0.30)\end{array}$ & $\begin{array}{l}68.37 \\
(1.83)\end{array}$ \\
\hline $\mathrm{VC}+B$. subtilis & $\begin{array}{l}43.50 \\
(1.64)\end{array}$ & $\begin{array}{l}59.50 \\
(1.77)\end{array}$ & $\begin{array}{l}71.17 \\
(1.85)\end{array}$ & $\begin{array}{l}39.06 \\
(1.59)\end{array}$ & $\begin{array}{c}04.50 \\
(0.87)\end{array}$ & $\begin{array}{l}43.55 \\
(1.64)\end{array}$ \\
\hline FYM + B. subtilis & $\begin{array}{l}21.27 \\
(1.33)\end{array}$ & $\begin{array}{l}52.40 \\
(1.72)\end{array}$ & $\begin{array}{l}48.17 \\
(1.68)\end{array}$ & $\begin{array}{l}35.50 \\
(1.55)\end{array}$ & $\begin{array}{c}01.50 \\
(0.17)\end{array}$ & $\begin{array}{l}31.77 \\
(1.50)\end{array}$ \\
\hline $\mathrm{MOC}+$ B. subtilis & $\begin{array}{l}15.50 \\
(1.19)\end{array}$ & $\begin{array}{l}16.50 \\
(1.22)\end{array}$ & $\begin{array}{l}34.80 \\
(1.54)\end{array}$ & $\begin{array}{l}09.30 \\
(0.96)\end{array}$ & $\begin{array}{l}00.50 \\
(0.30)\end{array}$ & $\begin{array}{l}15.32 \\
(1.18)\end{array}$ \\
\hline Mean & $\begin{array}{c}36.33 \\
(1.56)\end{array}$ & $\begin{array}{l}56.67 \\
(1.75)\end{array}$ & $\begin{array}{c}67.04 \\
(1.82)\end{array}$ & $\begin{array}{l}47.65 \\
(1.68)\end{array}$ & $\begin{array}{c}05.20 \\
(0.72)\end{array}$ & \\
\hline
\end{tabular}

S.Ed. $\pm=$ For treatment $=0.022$, for days $=0.016$, for treatment $\mathrm{x}$ days $=0.042 ; \mathrm{CD}(P=0.05)=$ For treatment $=0.044$, for days $=0.032$, for treatment $\mathrm{x}$ days $=0.084$; Figures in the parentheses are logarithm-transformed values. 
Table 2. Effect of substrate based bioformulations of Pseudomonas fluorescens, Trichoderma viride and Bacillus subtilis on reduction of bacterial wilt incidence in tomato, brinjal and chilli

\begin{tabular}{|c|c|c|}
\hline Treatments & Wilt incidence $(\%)^{*}$ & $\begin{array}{l}\text { Disease reduction over control } \\
(\%)\end{array}$ \\
\hline Vermicompost $(\mathrm{VC})+P$. fluorescens & $\begin{array}{l}17.17 \\
(22.19)^{\mathrm{a}}\end{array}$ & 81.85 \\
\hline Farm yard manure $(\mathrm{FYM})+P$. fluorescens & $\begin{array}{l}29.15 \\
(30.55)^{b}\end{array}$ & 69.19 \\
\hline Mustard oil cake $(\mathrm{MOC})+P$. fluorescens & $\begin{array}{l}37.75 \\
(35.25)^{\mathrm{c}}\end{array}$ & 62.00 \\
\hline $\mathrm{VC}+T$. viride & $\begin{array}{l}42.65 \\
(36.56)^{c}\end{array}$ & 54.92 \\
\hline $\mathrm{FYM}+T$. viride & $\begin{array}{l}24.40 \\
(29.24)^{\mathrm{b}}\end{array}$ & 74.21 \\
\hline $\mathrm{MOC}+T$. viride & $\begin{array}{l}19.80 \\
(25.37)^{\mathrm{a}}\end{array}$ & 79.07 \\
\hline $\mathrm{VC}+$ B. subtilis & $\begin{array}{l}25.20 \\
(30.71)^{\mathrm{b}}\end{array}$ & 73.36 \\
\hline $\mathrm{FYM}+$ B. subtilis & $\begin{array}{l}37.20 \\
(34.75)^{\mathrm{c}}\end{array}$ & 60.68 \\
\hline $\mathrm{MOC}+B$. subtilis & $\begin{array}{l}43.20 \\
(37.90)^{\mathrm{c}}\end{array}$ & 54.33 \\
\hline Control (Untreated) & $\begin{array}{l}94.60 \\
(81.55)^{d}\end{array}$ & - \\
\hline $\operatorname{SEd}( \pm)$ & $(1.62)$ & \\
\hline $\mathrm{CD}(P=0.05)$ & $(3.24)$ & \\
\hline
\end{tabular}

* Figures in the parentheses are angular transformed value

Table 3. Effect of substrate based bioformulations of Pseudomonas fluorescens, Trichoderma viride and Bacillus subtilis on enhancement of yield in tomato, brinjal and chilli

\begin{tabular}{llll}
\hline Treatments & Tomato yield (t/ha) & Brinjal yield (t/ha) & Chilli yield (t/ha) \\
\hline Vermicompost (VC) + P. fluorescens & 36.10 & 27.60 & 26.30 \\
Farm yard manure (FYM) + P. fluorescens & 32.90 & 21.20 & 21.20 \\
Mustard oil cake (MOC) + P. fluorescens & 27.30 & 19.40 & 17.40 \\
VC + T. viride & 30.40 & 24.60 & 23.50 \\
FYM + T. viride & 24.00 & 21.40 & 20.60 \\
MOC + T. viride & 33.35 & 27.40 & 31.80 \\
VC + B. subtilis & 23.93 & 24.98 & 21.77 \\
FYM + B. subtilis & 21.45 & 19.65 & 16.45 \\
MOC + B. subtilis & 19.66 & 17.33 & 15.42 \\
Control (Untreated) & 01.65 & 01.98 & 01.22 \\
SEd $( \pm)$ & 01.44 & 01.15 & 01.65 \\
CD $(P=0.05)$ & 02.88 & 02.30 & 03.30 \\
\hline
\end{tabular}

bioagents applied against the pathogens (Papavizas, 1985). Parakhia and Vaishnav (1986) observed that seed treatment with wheat husk-bran culture of T. harzianum followed by soil drenching could successfully control $R$. bataticola infection in chick pea and increase crop yield. Similarly, Vidya (1995) used combination of talc-based formulation of T. harzianum + vermiculite-wheat bran formulation for soil application and effectively managed $M$. phaseolina root rot disease of mung bean resulting higher crop yield.

\section{REFERENCES}

Alexander M. 1997. Introduction to soil microbiology. John Wiley and Sons, New York. 212 pp. 
Anuratha CS, Gnanamanickam SS. 1990. Biological control of bacterial wilt caused by Pseudomonas solanacearum in India with antagonistic bacteria. Plant Soil 124: 109-116.

Aspiras RB, Dela Cruz AR. 1985. Potential biological control of bacterial wilt in tomato and potato with Bacillus polymyxa $\mathrm{Fu} 6$ and Pseudomonas fluorescens. pp. 89-92. In: Persely GD. (Ed.). Bacterial wilt disease in Asia and the South Pacific. ACIAR Proceedings, No. 13.

Bora LC. 2008. Use of Pseudomonas fluorescens as bioformulation for management of wilt disease caused by Ralstonia solanacearum. Tropic Agric. 85(2): 57-61.

Bora LC, Popy B. 2008. Biological control strategies for management of bacterial wilt of brinjal (Solanum melongena L.). J Mycol Pl Pathol. 38(3): 542-545.

Bora LC, Deka SN. 2007. Wilt disease suppression and yield enhancement in tomato by application of Pseudomonas fluorescens - based bioformulation 'Biofor-Pf' in Assam. Indian J Agric Sci. 77(8): 490494.

Bora LC, Das M, Das BC. 2000. Influence of microbial antagonists and soil amendments on bacterial wilt severity and yield of tomato (Lycopersicon esculentum). Indian J Agric Sci. 70(6): 390-392.

Bull CT. 1987. Wheat root colonization by disease suppressive bacteria and the effect of population size on severity of take-all caused by Gaeumannomyces graminis var. tritici. M.S. thesis Fleming West State Univ. Pullman. 75-81 pp.

Burr TJ, Schroth MN, Suslow T. 1978. Increased potato yields by treatment of potato seed pieces with specific strains of Pseudomonas fluorescens and P. putida. Phytopathol. 68: 1377-1388.

Chellemi DO, Olson SM, Scott JW. 1994. Field evaluation of tomato genotypes for resistance to bacterial wilt. Proc Flo State Hort Soc. 107: 151-153.

Danielson RM, Davey CB. 1973. Non-nutritional factors affecting the growth of Trichoderma in culture. Soil Biol Biochem. 5: 495-504.

Hadar Y, Chet I, Henis Y. 1979. Biological control of Rhizoctonia solani damping-off with wheat bran culture of Trichoderma harzianum. Phytopathol. 69: 64-66.

Hoitink HAJ, Fahy PC. 1986. Basis for the control of soil borne plant pathogens with compost. Ann Rev Phytopathol. 24: 93-144.

Kloepper JW, Schroth MN. 1981. Relationship of in vitro antibiosis of plant growth promoting rhizobacteria to plant growth and the displacement of root microflora. Phytopathol. 71: 1020-1024.

Kohli RR, Srivastava AK, Shivankar VJ. 1988. Organic culture in citrus cultivation. Indian Horti. 43(1): 12-14.

Nautyal CS. 2000. Biocontrol of plant diseases for agricultural sustainability pp. 9-23. In: Upadhyay RK, Mukerji KG, Chamola BP. (Eds.). Biocontrol potential and its exploitation in sustainable agriculture. Kluwer Academic/Plenum Publishers, New York.

Papavizas GC. 1985. Trichoderma and Gliocladium: Biology, ecology and potential for biocontrol. Ann Rev Phytopathol. 23: 23-54.

Parakhia AM, Vaishnav MU. 1986. Biocontrol of Rhizoctonia bataticola. Indian Phytopathol. 39: 439.

Sharif ABM, Hakim MA, Onyuso M. 2003. Effect of manure and fertilizers on the growth and yield of potato. Pak J Biol Sci. 6(14): 1243-1246.

Sigee DC. 1993. Bacterial plant pathology: Cell and molecular aspects. Cambridge University Press, London. 337 pp.

Suslow TV, Schroth MN. 1982. Rhizobacteria of sugarbeets: effects of seed application and root colonization on yield. Phytopathol. 72: 199-206.

Ushasree NN, Chandrasekaran S, Govindasamy R. 1989. Humic acid and its influence on crop plants, pp. 63. In: National seminar on humic acid in agriculture. Annamalai University, Tamil Nadu (Abstr.).

Vidya R. 1995. Studies on biological control of mung bean root rot [Macrophomina phaseolina (Tassi)] Goid by Trichoderma viride Pers. M.Sc. Thesis, Tamil Nadu Agric. Univ., Coimbatore, India 66 pp.

Vidhyasekaran P, Muthamilan M. 1995. Development of formulations of Pseudomonas fluorescens for control of chickpea wilt. Plant Dis. 79: 782-786. 